\title{
Effect of rock fragments content on water consumption, biomass and water-use efficiency of plants under different water conditions
}

\author{
Meixia Mi ${ }^{a}$, Ming'an Shao ${ }^{\mathrm{a}, \mathrm{b}, *}$, Bingxia Liu ${ }^{\mathrm{c}}$ \\ ${ }^{a}$ Key Laboratory of Ecosystem Network Observation and Modeling, Institute of Geographic Sciences and Natural Resources Research, Chinese Academy of \\ Sciences, Beijing 100101, China \\ b State Key Laboratory of Soil Erosion and Dryland Farming on the Loess Plateau, Institute of Soil and Water Conservation, Chinese Academy of Sciences E' \\ Ministry of Water Resources, Yangling 712100, China \\ ${ }^{\mathrm{c}}$ Key Laboratory of Agricultural Water Resources, Center for Agricultural Resources Research, Institute of Genetics and Developmental Biology, Chinese \\ Academy of Sciences, 286 Huaizhong Road, Shijiazhuang 050021, China
}

\section{A R T I C L E I N F O}

\section{Article history}

Received 22 December 2015

Received in revised form 18 May 2016

Accepted 16 June 2016

Available online 15 July 2016

\section{Keywords:}

Rock fragment

Plant

Water consumption

Biomass

Water-use efficiency

\begin{abstract}
A B S T R A C T
The proportion of rock fragments in soil affects water availability and therefore the characteristics of plants. The objective of this study was to evaluate the effect of rock-fragment content on plant water consumption, biomass, growth and water-use efficiency (WUE) under different water conditions. Four gravimetric treatments of rock-fragment contents $(0,10,30$ and $50 \%)$ and four treatments of water content were tested in sandy loamy soils. The water contents of the rock-free soil were $15-19 \%(80-100 \%$ of field capacity), $11-15 \%$ (60-80\% of field capacity), 9-11\% (47-60\% of field capacity) and 6-9\% (32-47\% of field capacity). Transpiration, plant height, basal stem diameter and biomass of korshinsk peashrubs in the treatments were measured and compared. Plants grown in the soil with rock fragments transpired less, especially under well-watered conditions. The mean daily transpiration of plants in the soils with 30 and 50\% rock-fragment contents was $18 \%(P=0.021)$ and $34 \%(P=0.001)$ lower, respectively, in 2014 , and $25 \%(P=0.008)$ and $31 \%(P=0.002)$ lower, respectively, in 2015 relative to the soil without rock fragments and was not lower in the soil with $10 \%$ rock fragments. Plant height, basal stem diameter and biomass did not differ significantly between rock-fragment contents of 0 and $30 \%$ but were lower at $50 \%$. WUE, the ratio between total transpiration and biomass, was highest at $30 \%$ and then decreased at $50 \%$. Increasing plant water stress could thus improve WUE. The rock fragments in the soil had significant effects on plant water consumption, biomass, growth and WUE. Optimizing the rock-fragment content is necessary when the relationships between plants and water in stony ecosystems are evaluated.
\end{abstract}

(c) 2016 Elsevier B.V. All rights reserved.

\section{Introduction}

A soil rock fragment is defined as a particle with a diameter $>2 \mathrm{~mm}$. Fragments forming as a result of processes of soil genesis and human activity exist at the soil surface and within the soil. Stony soils are widespread and can reach land-cover ratios up to $60 \%$ in the Mediterranean region of Western Europe (Poesen and Lavee, 1994). The proportion of stony soil is $>30 \%$ on the Loess Plateau of China (Hou, 1993).

The presence of rock fragments significantly affects hydrological functioning such as water storage, infiltration and evaporation and soil hydraulic properties such as hydraulic conductivity and water retention (Van Wesemael et al., 1996; Ma and Shao, 2008;

\footnotetext{
* Correspondence to: 11\#, Da Tun Road, Chao Yang District, Beijing, China.

E-mail address: shaoma@igsnrr.ac.cn (M. Shao).
}

Li et al., 2008; Zhou et al., 2009; Baetens et al., 2009; Ma et al., 2010; Novák et al., 2011; Tetegan et al., 2011). Water movement in, and the hydraulic properties of, soils are strongly dependent on the availability of water for plants. Rock fragments in stony areas should therefore be considered in studies of water availability for plants and of water exchange among plants, rock fragments and soils.

Tetegan et al. (2011) proposed pedotransfer functions based on the linear relationship between the available water content (AWC) of rock fragments and the Napierian logarithm of bulk density and the relationship between water content at -100 and -15 $840 \mathrm{hPa}$. The simulation showed that excluding 30\% of the pebbles in a stony horizon underestimated the soil available water content (SAWC) by $5 \%$ for chert pebbles and by $33 \%$ for chalk pebbles. Novák and Knnava (2012) demonstrated that the presence of stones can decrease soil water-holding capacity and hydraulic conductivity, which can decrease the availability of soil water for trees. Tetegan 
Table 1

Main physical properties of the fine soil.

\begin{tabular}{|c|c|c|c|c|}
\hline Sand >0.02 mm (\%) & Silt $0.02-0.002 \mathrm{~mm}(\%)$ & Clay <0.002 mm (\%) & Organic content (\%) & Field capacity $\left(\mathrm{cm}^{3} \mathrm{~cm}^{-3}\right)$ \\
\hline 80.3 & 13.6 & 6.1 & 0.89 & 0.190 \\
\hline
\end{tabular}

et al. (2015a) subsequently improved the method proposed in 2011 (Tetegan et al., 2011) to calculate the SAWC at a regional scale (36 200 ha). They demonstrated that rock fragments could contribute to the AWC of stony soils. SAWC could thus be underestimated if rock-fragment content is neglected. Water exchange would be more complex when plants are added to the system. Tetegan et al. (2015b) included the dynamics of water exchange between fine and stony soil. They demonstrated that rock fragments in soil could act as water reservoirs for plants. Water was exchanged between rock fragments and soils, plants and soils, and plants and rock fragments.

The growth and physiological features of plants should differ between stony and rock-free soils due to the effect of rock fragments on the water availability for plants and water exchange. Danalatos et al. (1995) reported that water conservation was generally better in stony soils under conditions of moderate water stress, and the presence of cobbles on the soil surface increased total drymatter yield of rainfed wheat by $20 \%$. The presence of stones in soil also affects the growth of plant roots. Estrada-Medina et al. (2013) demonstrated that rock fragments changed the distribution of root systems. Plant roots can grow in both soil and rock. Changes in plant growth have been attributed to hydraulic and nutrient redistribution resulting from the presence of rock fragments (Carrick et al., 2013). Root growth is linked to the compressive strength of rocks; the penetration resistance of soil ranges from 2 to $4 \mathrm{MPa}$ (Arshad et al., 1996), and root growth is restricted above this range (Schwinning, 2013).

In addition to changing the yield and root distribution of plants, rock fragments can also change other features of plants such as transpiration (a feature of water consumption), stem height and diameter (features of plant growth), and water-use efficiency (WUE). Few studies, however, have investigated changes in these features, which limits our understanding of the features of plant growth in stony soil.

We hypothesized that (1) the responses of plant transpiration, stem height and diameter, and biomass to water conditions can be affected by the rock-fragment content of the soil and (2) rock-fragment content would affect WUE under different water conditions. The objectives of this study were therefore to (i) assess whether the features of plants such as transpiration, stem height and diameter, and biomass respond to rock-fragment content under different water conditions, and (ii) quantify and compare WUEs and then determine a feasible strategy of management of rock fragments and water conditions for increasing WUE.

\section{Materials and methods}

\subsection{Description of the sampling site}

The experiment was conducted at the Shenmu Erosion and Environmental Research Station of the Institute of Soil and Water Conservation, Chinese Academy of Sciences. The station is in the Liudaogou catchment on the northern Loess Plateau of China $\left(38^{\circ} 46^{\prime}-38^{\circ} 51^{\prime} \mathrm{N}, 110^{\circ} 21^{\prime}-110^{\circ} 23^{\prime} \mathrm{E} ; 1081.0-1273.9 \mathrm{~m}\right.$ a.s.l.). This area has a semiarid climate with a mean annual temperature of $8.6^{\circ} \mathrm{C}$ and a mean annual precipitation of $412 \mathrm{~mm}$ (1996-2015) falling mainly from July to September. The mean frost-free period is 169 days, and the mean annual pan evaporation is $785 \mathrm{~mm}$ (Jia et al., 2011).

The main rock fragments in the catchment are concretions of calcium carbonate formed from loessial deposits that have a high
Table 2

Size distribution of the rock fragments.

\begin{tabular}{lllll}
\hline $2-10 \mathrm{~mm}(\%)$ & $10-20 \mathrm{~mm}(\%)$ & $20-30 \mathrm{~mm}(\%)$ & $30-40 \mathrm{~mm}(\%)$ & $>40 \mathrm{~mm}(\%)$ \\
\hline 2.15 & 6.69 & 52.92 & 11.38 & 26.86 \\
\hline
\end{tabular}

content of calcium carbonate (Zhu and Shao, 2008). The concretions have formed by the synthetic action of pedogenesis, soil erosion, and human activity and are randomly distributed in and on the surface of the soil. These rock fragments have the capacity to absorb water.

The soil and rock fragments for this study were collected from the catchment. The soil used in this study was sandy loam, classified according to the ISSS (International Society of Soil Science) system. The main physical properties of the soil are presented in Table 1. Field capacity was determined by the modified Wilcox method (Hanks et al., 1954). The size distribution of the rock fragments is presented in Table 2. Fragment sizes of $20-30 \mathrm{~mm}$ represented the largest proportion ( $>50 \%$ ), followed by fragments $>40 \mathrm{~mm}$.

\subsection{Experimental design and treatments}

The experiment was conducted beneath a mobile plastic rain shelter from May to October 2014 and 2015 using PVC columns $1 \mathrm{~m}$ high and $20 \mathrm{~cm}$ in diameter. The fine $(<2 \mathrm{~mm})$ or stony soil was packed to a depth of $85-90 \mathrm{~cm}$. Soil crusting was avoided by providing irrigation water through a tube ( $2 \mathrm{~mm}$ ID) inserted from the surface to the middle of the fine or stony soil in the columns. The korshinsk peashrub (Caragana korshinskii Kom.), a perennial shrub commonly used for vegetation recovery on the Loess Plateau, was chosen as a test plant for this study. Peashrub seeds were sown in the columns in August 2012, and seedlings were thinned to two plants per column.

Four rock-fragment contents were tested: 0, 10, 30 and 50\% (gravimetric contents), abbreviated as A, B, C and D, respectively. Four water treatments were also tested. For the fine soil, the four water treatments were $15-19 \%$ ( $80-100 \%$ of field capacity), $11-15 \%$ (60-80\% of field capacity), 9-11\% (47-60\% of field capacity, average water content in a wet year) and $6-9 \%$ (32-47\% of field capacity, average water content in a dry year), abbreviated as $W_{1}, W_{2}, W_{3}$ and $\mathrm{W}_{4}$, respectively. The corresponding gravimetric water contents were $11.3-14.3,8.3-11.3,6.8-8.3$, and $4.5-6.8 \%$, respectively. The bulk density of the packed fine soil was $1.33 \mathrm{~g} \mathrm{~cm}^{-3}$, and the average bulk density of the rock fragments was $2.05 \mathrm{~g} \mathrm{~cm}^{-3}$. The water content of the stony soil was determined by:

$\theta_{m T}=R_{m} \theta_{\mathrm{mrf}}+\left(1-R_{m}\right) \theta_{\mathrm{mfe}}$

where $\theta_{m T}, \theta_{m f e}$ and $\theta_{m r f}$ are the water contents of the stony soil, fine soil and rock fragments, respectively; and $R_{m}$ is the gravimetric rock-fragment content. $\theta_{m r f}$ was calculated by (Shao et al., 2009):

$\theta_{\text {mrf }}=a\left(1-e^{-b \theta}{ }_{\mathrm{mfe}}\right)$

where $\mathrm{a}$ and $\mathrm{b}$ are the empirical parameters. This equation expresses the relationship between the water contents of the fine soil and the rock fragments (calcium carbonate concretions) under stable conditions (i.e. no water is exchanged between the fine soil and the rock fragments). Shao et al. (2009) indicated that the rock-fragment content did not significantly affect the relationship between the water contents of the rock fragments and the fine soil. We thus used the same empirical parameters in the different 
rock-fragment treatments. The values of a and $b$ were obtained by measuring a series of fine-soil water contents and rock-fragment water contents under equilibrium conditions. In this study, a was 0.082 and b was $14.429(N=35, R=0.88, S E=0.012$; $N$ is the number of samples; $R$ is the correlation coefficient of the fit; and $S E$ is the standard error of the estimation). The four water treatments, $W_{1}, W_{2}, W_{3}$ and $W_{4}$, were thus 10.8-13.6, 8.0-10.8, 6.6-8.8 and $4.5-6.6 \%$ for the columns with $10 \%$ rock fragments; $9.9-12.2$, $7.5-9.9,6.2-7.5$ and $4.3-6.2 \%$ for the columns with $30 \%$ rock fragments; and 8.9-10.8, 7.0-8.9, 5.9-7.0 and 4.2-5.9\% for the columns with 50\% rock fragments, respectively. Maintaining the water contents served two purposes: to restrict changes in water content to below field capacity and to compare the indexes (e.g. transpiration and plant growth) among the rock-fragment contents.

Water added to the columns was determined from the amounts of water in the fine soil and rock fragments under equilibrium conditions (Eq. (2)). The amount of water added through the supply tube was calculated by subtracting the weights of the fresh plants, an empty column, the layer of vermiculite and the water-supply tube from the total weight of a column and dividing by the dry weight of the fine/stony soil. To avoid destroying the peashrubs, we estimated the aboveground plant fresh weight $(W, \mathrm{~g})$ from the height $(H)$ and basal stem diameter $(D)$ allometrically at the time of measurement (Feng et al., 1999):

$\operatorname{Ln}(W)=\mathrm{a} \times \operatorname{Ln}\left(D^{2} H\right)+\mathrm{b}$ ( $\mathrm{a}$ and $\mathrm{b}$ are the empirical parameters). $H$ and $D$ were measured by a measuring tape $(1 \mathrm{~mm})$ and vernier calipers $(0.01 \mathrm{~mm})$, respectively. The weights of the fresh plants changed with time (Fig. 2) so were recalculated after measuring $H$ and $D$ (approximately one month). After weighing each time, water was added until reaching the upper limit of the water content. The columns were reweighed after 2-4 days. Water content was not measured during the experimental period, so the gravimetric water content of each treatment was calculated from the water balance. The average of the water content of the upper limit and at weighing represented the mean water content during this period.

The initial water contents of the fine soil and the rock fragments were 0.0060 and $0.0056 \mathrm{~m}^{3} \mathrm{~m}^{-3}$, respectively. The saturated water contents of the fine soil and the rock fragments were 0.40 and $0.16 \mathrm{~m}^{3} \mathrm{~m}^{-3}$, respectively. Each treatment had three replicates, for a total of 48 columns ( 4 (rock fragments contents) $\times 4$ (water contents $) \times 3$ (replicates)). Air-dried samples of fine soil $(<2 \mathrm{~mm})$ were mixed well with the rock fragments (mostly $10-50 \mathrm{~mm}$ ), and the soil/rock-fragment mixtures were then uniformly packed into the PVC columns. Some vermiculite was added to the surface for preventing evaporation. The bottoms of the columns were sealed.

Water consumption was calculated from the water balance using the difference in the weights of the columns before and after the interval of adding water. Daily transpiration rates were calculated as the average water consumption over the 2-4 day period. The changes in plant weights were ignored, because the weights changed little during the 2-4 days relative to the changes of water content. Wu et al. (2011b,c) also ignored the growth of the maize over 2-5 days and of the winter wheat over 1-3 days in pots experiment. During the period of experiment, we also confirmed the reasonability of ignoring the changes of plant weight. For example, from 12 June to 10 July in 2014, the aboveground biomass of $\mathrm{AW}_{1}$ increased by $0.43 \mathrm{~g}$ per day. The daily transpiration was $0.244 \mathrm{Kg}$ during this period. From 5 June to 4 July in 2015, the aboveground biomass of $\mathrm{AW}_{1}$ and $\mathrm{BW}_{2}$ increased by 0.39 and $0.65 \mathrm{~g}$ per day, respectively. The corresponding daily transpiration was $0.336 \mathrm{Kg}$ and $0.240 \mathrm{Kg}$, respectively. The changes in plant weights in the three examples were the largest of all. The pan evaporation of water was also measured to represent the weather conditions during the experiment. The diameter of the pan was $20 \mathrm{~cm}$.

The experiment was conducted during the growing seasons (May to September) of the peashrubs in 2014 and 2015. The heights and basal stem diameters were measured once a month. We collected the stems and leaves of the plants at the end of the experiment in September 2015. The columns were cut to collect the plant roots. All plant tissues were oven-dried $\left(80^{\circ} \mathrm{C}\right)$ and then weighed $(0.01 \mathrm{~g})$.

\subsection{Statistical analysis}

One-way analyses of variance (ANOVAs) were used to examine the significance of the differences in water content, transpiration, plant growth and biomass among treatments. A least significant difference [LSD (0.05)] test was used if differences were significant. The data were analyzed using SPSS 19.0 statistical software (International Business Machines Corporation (IBM), USA). The plots were mapped using SigmaPlot 12.0 (System Statistical Analysis Software Corporation (SYSTAT), USA).

\section{Results and discussion}

\subsection{Changes of water content during the experiment}

The ranges and averages of the water content for each treatment during the experiment are shown in Table 3. An ANOVA indicated that all differences in average water contents of each treatment with the same rock-fragment content were significant (with 95\% confidence intervals). Comparison of the water contents of the different rock-fragment treatments (Table 3) showed that (i) the difference of water content between $\mathrm{AW}_{2}$ and $\mathrm{BW}_{2}$ was not significant in 2014; (ii) the differences of water content among $A W_{2}$, $\mathrm{BW}_{2}$ and $\mathrm{DW}_{1}$, among $\mathrm{AW}_{3}, \mathrm{BW}_{3}$ and $\mathrm{CW}_{3}$, and among $\mathrm{AW}_{4}, \mathrm{BW}_{4}$ and $\mathrm{CW}_{4}$ were not significant in 2015; and (iii) the differences of water content between $\mathrm{AW}_{4}$ and $\mathrm{DW}_{3}$ and between $\mathrm{BW}_{4}$ and $\mathrm{DW}_{4}$ were not significance in 2015 . The water contents differed significantly among the other treatments. The coefficient of variation for the water content as a function of time for each treatment was $<6.5 \%$ in 2014 and $<6 \%$ in 2015, and the mean standard errors were $<0.005 \mathrm{~cm}^{3} \mathrm{~cm}^{-3}$ in 2014 and $<0.002 \mathrm{~cm}^{3} \mathrm{~cm}^{-3}$ in 2015. The above average water contents were all maintained at the desired value indicated in Section 2.2 .

\subsection{Water consumption}

Daily and total transpiration were determined by weighing after inhibiting evaporation. Daily transpiration was measured 34 times in 2014 (from 19 May to 20 September) and 29 times in 2015 (from 12 May to 16 September), and the dynamics of daily transpiration were consistent with the pan evaporation (Fig. 1). The daily and total transpiration of all treatments were compared by an ANOVA (with 95\% confidence intervals). The dynamics of daily transpiration per plant during the experiment are shown in Fig. 1.

Daily transpiration was higher in the treatments with higher water contents in both the fine and stony soils. Daily transpiration in the soil with no rock fragments $(0 \%)$ was higher for $\mathrm{AW}_{1}$ and $\mathrm{AW}_{2}$ than for $\mathrm{AW}_{3}$ and $\mathrm{AW}_{4}$ and was higher for $\mathrm{AW}_{3}$ than for $\mathrm{AW}_{4}$ (Fig. 1 and Table 4). The changing trends of daily transpiration were similar in the other rock-fragment treatments. Daily transpiration did not differ significantly between $\mathrm{AW}_{1}$ and $\mathrm{AW}_{2}$ in the rock-free soil ( $0 \%$ ) and between $\mathrm{CW}_{1}$ and $\mathrm{CW}_{2}$ in the soil with $30 \%$ rock-fragment content. Daily transpiration, however, differed significantly between $\mathrm{BW}_{1}$ and $\mathrm{BW}_{2}$ in the treatments with $10 \%$ rock-fragment content in 2015 and between $\mathrm{DW}_{1}$ and $\mathrm{DW}_{2}$ in the treatments with $50 \%$ rock-fragment content. Maintaining similar daily transpiration is reasonable under high water conditions, even though the water contents differed significantly. Various plants physiological indices (such as transpiration rate, photosynthetic rate, and plant height) began to decrease when water content 
Table 3

Changes of water content during the experiment.

\begin{tabular}{|c|c|c|c|c|c|}
\hline \multirow[t]{2}{*}{ Rock-fragment content (\%) } & \multirow[t]{2}{*}{ Treatment } & \multicolumn{2}{|l|}{2014} & \multicolumn{2}{|l|}{2015} \\
\hline & & Range of water content $\left(\mathrm{g} \mathrm{g}^{-1}\right)$ & Average water content $\left(\mathrm{g} \mathrm{g}^{-1}\right)$ & Range of water content $\left(\mathrm{gg}^{-1}\right)$ & Average water content $\left(\mathrm{g} \mathrm{g}^{-1}\right)$ \\
\hline \multirow[t]{4}{*}{0} & $\mathrm{AW}_{1}$ & $0.121-0.138$ & 0.130 & $0.097-0.136$ & 0.119 \\
\hline & $\mathrm{AW}_{2}$ & $0.099-0.110$ & $0.105^{*}$ & $0.080-0.107$ & $0.093^{*}$ \\
\hline & $\mathrm{AW}_{3}$ & $0.071-0.080$ & 0.077 & $0.062-0.080$ & $0.070 \dagger$ \\
\hline & $\mathrm{AW}_{4}$ & $0.050-0.064$ & 0.060 & $0.055-0.065$ & $0.061 \ddagger \S$ \\
\hline \multirow[t]{4}{*}{10} & $\mathrm{BW}_{1}$ & $0.117-0.131$ & 0.127 & $0.095-0.131$ & 0.113 \\
\hline & $\mathrm{BW}_{2}$ & $0.092-0.104$ & $0.100^{*}$ & $0.070-0.105$ & $0.090^{*}$ \\
\hline & $\mathrm{BW}_{3}$ & $0.069-0.078$ & 0.075 & $0.060-0.077$ & $0.069 \dagger$ \\
\hline & $\mathrm{BW}_{4}$ & $0.057-0.064$ & 0.061 & $0.052-0.063$ & $0.058 \ddagger \#$ \\
\hline \multirow[t]{4}{*}{30} & $\mathrm{CW}_{1}$ & $0.112-0.119$ & 0.115 & $0.090-0.116$ & 0.105 \\
\hline & $\mathrm{CW}_{2}$ & $0.081-0.096$ & 0.089 & $0.072-0.095$ & 0.085 \\
\hline & $\mathrm{CW}_{3}$ & $0.061-0.073$ & 0.068 & $0.063-0.072$ & $0.068 \dagger$ \\
\hline & $\mathrm{CW}_{4}$ & $0.048-0.060$ & 0.056 & $0.056-0.061$ & $0.059 \ddagger$ \\
\hline \multirow[t]{4}{*}{50} & $\mathrm{DW}_{1}$ & $0.092-0.103$ & 0.098 & $0.076-0.103$ & $0.091^{*}$ \\
\hline & $\mathrm{DW}_{2}$ & $0.080-0.087$ & 0.084 & $0.063-0.088$ & 0.076 \\
\hline & $\mathrm{DW}_{3}$ & $0.060-0.068$ & 0.066 & $0.057-0.068$ & $0.064 \S$ \\
\hline & $\mathrm{DW}_{4}$ & $0.049-0.057$ & 0.055 & $0.051-0.059$ & 0.055\# \\
\hline
\end{tabular}

Note: The same symbols $\left({ }^{*}, \dagger, \uparrow, \S, \#\right)$ after the numbers in the same column indicate that the difference of water content among the treatments was not significant.

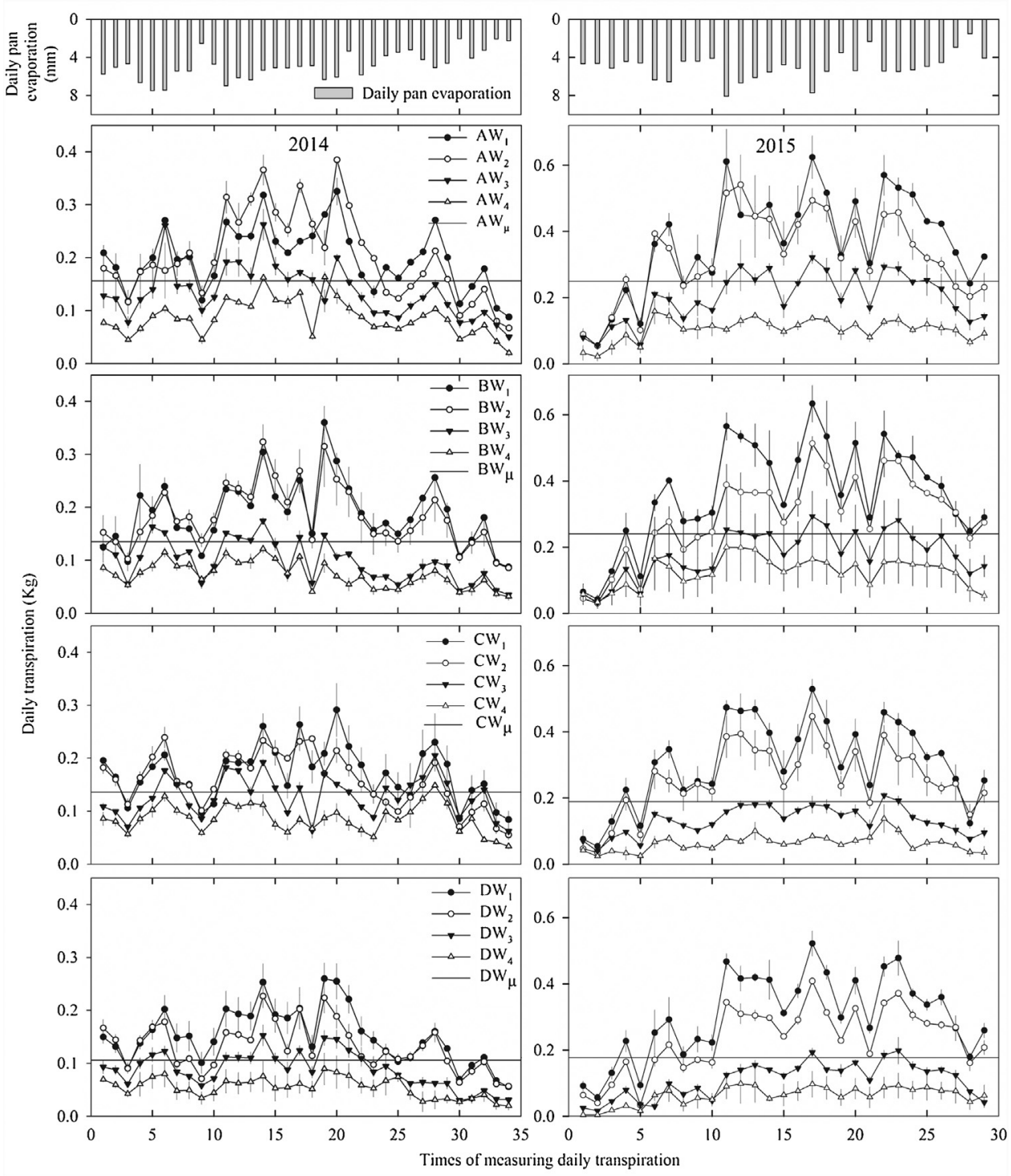

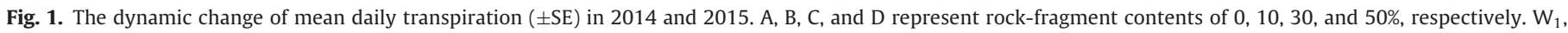

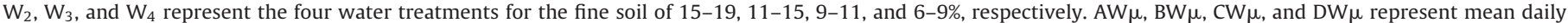
transpiration of the four water treatments for rock-fragment contents of $0,10,30$, and $50 \%$, respectively. 

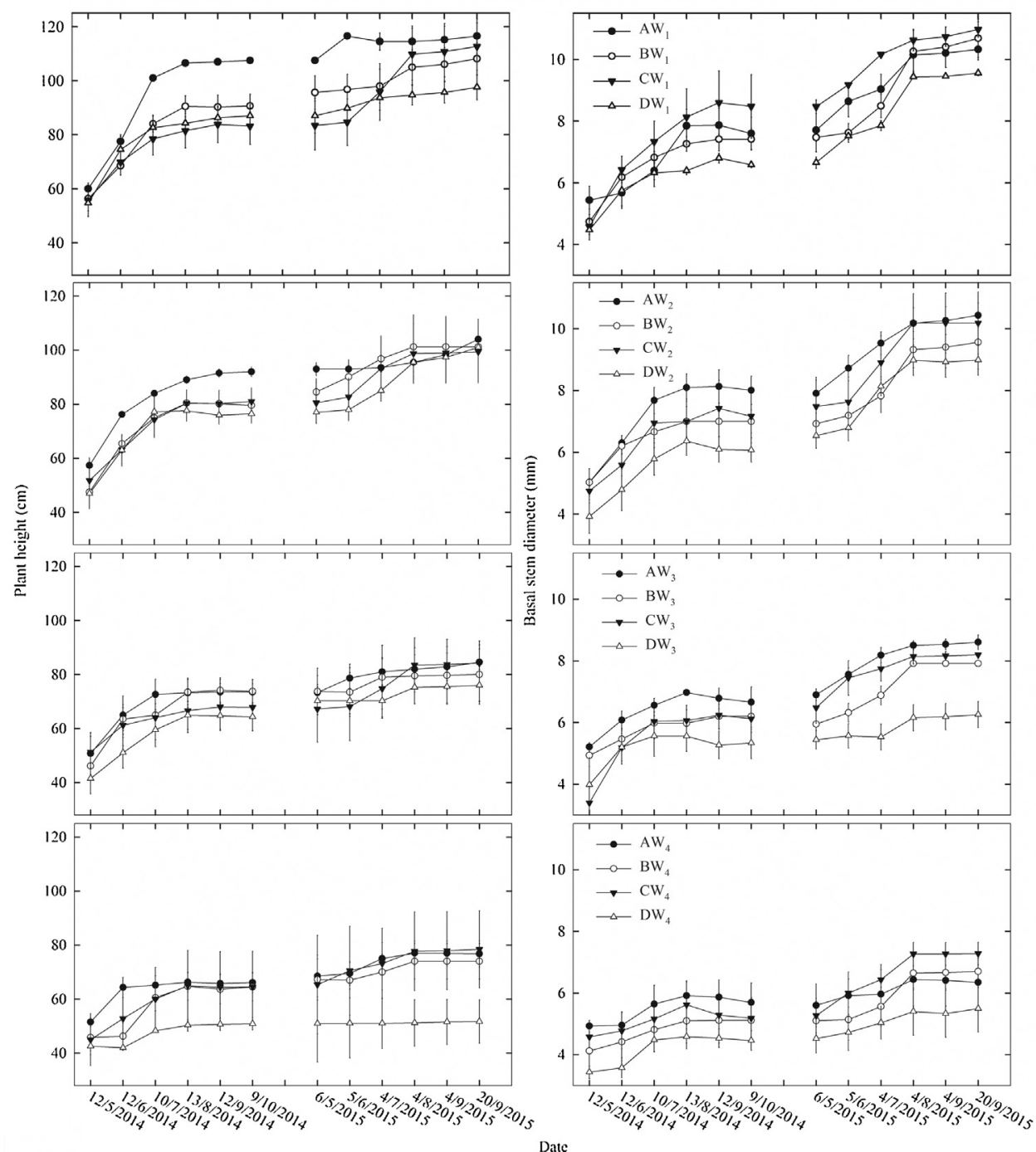

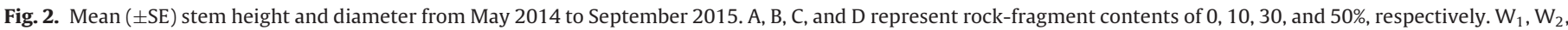
$W_{3}$, and $W_{4}$ represent the four water treatments for the fine soil of 15-19, 11-15, 9-11, and 6-9\%, respectively.

Table 4

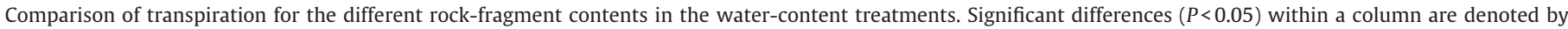
different letters.

\begin{tabular}{|c|c|c|c|c|c|}
\hline \multirow[t]{2}{*}{ Rock-fragment content (\%) } & \multirow[t]{2}{*}{ Treatment } & \multicolumn{2}{|l|}{2014} & \multicolumn{2}{|l|}{2015} \\
\hline & & Daily Transpiration (Kg) & Total transpiration $(\mathrm{Kg})$ & Daily transpiration (Kg) & Total transpiration $(\mathrm{Kg})$ \\
\hline \multirow[t]{4}{*}{0} & $\mathrm{AW}_{1}$ & $0.189 \mathrm{a}$ & $25.825 \mathrm{a}$ & $0.382 \mathrm{a}$ & $42.207 \mathrm{a}$ \\
\hline & $\mathrm{AW}_{2}$ & $0.188 \mathrm{a}$ & $25.705 \mathrm{a}$ & $0.336 \mathrm{ab}$ & $37.201 \mathrm{abc}$ \\
\hline & $\mathrm{AW}_{3}$ & 0.126 de & 16.829 de & 0.208 de & 23.067 ef \\
\hline & $\mathrm{AW}_{4}$ & $0.082 \mathrm{fg}$ & $11.034 \mathrm{fg}$ & $0.108 \mathrm{gh}$ & 11.815 hij \\
\hline \multirow[t]{4}{*}{10} & $\mathrm{BW}_{1}$ & $0.179 \mathrm{ab}$ & $24.867 \mathrm{ab}$ & $0.376 \mathrm{a}$ & $41.584 \mathrm{ab}$ \\
\hline & $\mathrm{BW}_{2}$ & $0.174 \mathrm{ab}$ & $23.981 \mathrm{abc}$ & $0.302 \mathrm{bc}$ & $33.633 \mathrm{~cd}$ \\
\hline & $\mathrm{BW}_{3}$ & $0.092 \mathrm{f}$ & $12.106 \mathrm{efg}$ & $0.186 \mathrm{ef}$ & $20.686 \mathrm{fg}$ \\
\hline & $\mathrm{BW}_{4}$ & $0.069 \mathrm{gh}$ & $9.063 \mathrm{~g}$ & $0.129 \mathrm{~g}$ & $14.169 \mathrm{gh}$ \\
\hline \multirow[t]{4}{*}{30} & $\mathrm{CW}_{1}$ & $0.163 \mathrm{bc}$ & $22.498 \mathrm{abc}$ & $0.318 \mathrm{bc}$ & $35.182 \mathrm{bcd}$ \\
\hline & $\mathrm{CW}_{2}$ & $0.148 \mathrm{~cd}$ & 19.766 bcd & $0.262 \mathrm{~cd}$ & 29.097 de \\
\hline & $\mathrm{CW}_{3}$ & $0.123 \mathrm{e}$ & $11.431 \mathrm{fg}$ & $0.136 \mathrm{fg}$ & $15.081 \mathrm{fgh}$ \\
\hline & $\mathrm{CW}_{4}$ & $0.082 \mathrm{fg}$ & $10.015 \mathrm{fg}$ & $0.065 \mathrm{~h}$ & $7.200 \mathrm{ij}$ \\
\hline \multirow[t]{4}{*}{50} & $\mathrm{DW}_{1}$ & $0.143 \mathrm{~cd}$ & $19.543 \mathrm{~cd}$ & 0.314 bc & $35.024 \mathrm{~cd}$ \\
\hline & $\mathrm{DW}_{2}$ & $0.123 \mathrm{e}$ & $15.147 \mathrm{def}$ & 0.239 de & 26.692 ef \\
\hline & $\mathrm{DW}_{3}$ & $0.081 \mathrm{fg}$ & $8.717 \mathrm{~g}$ & $0.112 \mathrm{gh}$ & $11.297 \mathrm{hji}$ \\
\hline & $\mathrm{DW}_{4}$ & $0.050 \mathrm{~h}$ & $9.237 \mathrm{~g}$ & $0.065 \mathrm{~h}$ & $7.177 \mathrm{j}$ \\
\hline
\end{tabular}

is below a critical value (Bielorai,1973; Sinclair et al., 1998; Wu et al., 2011b,c).

Daily transpiration tended to decrease as the proportion of rock fragments in the soil increased. The results of comparisons of mean daily transpiration for each rock-fragment content showed that the daily transpiration for plants grown without rock fragments (0\%) was higher than for plants grown with rock-fragment contents of 30 and 50\% (Table 5): 18 and 34\% higher, respectively, in 2014 and 
Table 5

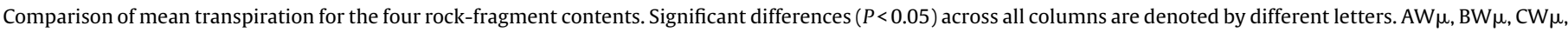
$\mathrm{DW} \mu$ represent mean daily transpiration of four water treatments for rock-fragment contents of $0,10,30$, and $50 \%$, respectively.

\begin{tabular}{|c|c|c|c|c|}
\hline \multirow[t]{2}{*}{ Rock-fragment content (\%) } & \multicolumn{2}{|l|}{2014} & \multicolumn{2}{|l|}{2015} \\
\hline & $\begin{array}{l}\text { Mean daily transpiration } \\
\left(\mathrm{AW}_{\mu}, \mathrm{Kg}\right)\end{array}$ & $\begin{array}{l}\text { Mean total transpiration } \\
\left(\mathrm{BW}_{\mu}, \mathrm{Kg}\right)\end{array}$ & $\begin{array}{l}\text { Mean daily transpiration } \\
\left(\mathrm{CW}_{\mu}, \mathrm{Kg}\right)\end{array}$ & $\begin{array}{l}\text { Mean total transpiration } \\
\left(\mathrm{DW}_{\mu}, \mathrm{Kg}\right)\end{array}$ \\
\hline 0 & $0.146 a$ & $20.932 \mathrm{a}$ & $0.259 a$ & $28.572 \mathrm{a}$ \\
\hline 10 & 0.128 ba & 17.766ab & $0.248 a$ & $27.518 \mathrm{a}$ \\
\hline 30 & $0.119 b$ & $17.237 a b$ & $0.195 b$ & $21.640 \mathrm{~b}$ \\
\hline 50 & $0.097 b$ & $14.207 \mathrm{~b}$ & $0.180 \mathrm{~b}$ & $20.048 b$ \\
\hline
\end{tabular}

25 and 31\% higher, respectively, in 2015. Daily transpiration was higher in the treatments with $10 \%$ rock-fragment content than the treatments with 30 and 50\% rock-fragment contents in 2015 (21 and $27 \%$ higher, respectively). This trend was associated with the water hydraulic conductivity. The saturated hydraulic conductivity previously reported for the calcium carbonate concretions in the Liudaogou catchment initially decreased with increasing rockfragment content to a minimum rock-fragment content of $40 \%$ and then increased (Zhou et al., 2009). The saturated hydraulic conductivity in our study was lowest for the rock-fragment content of $50 \%$. Novák and Kňava (2012) also demonstrated that stones in mountainous forest soil reduced the effective hydraulic conductivity of the soil. Rock fragments in the soil slow the movement of water to the roots, which decreases transpiration.

A comparison of daily transpiration also showed that the difference of transpiration in the different proportions of rock fragments decreased with water content. The descending order of daily transpiration for water-content treatment $\mathrm{W}_{1}$ was: $\mathrm{AW}_{1}>\mathrm{BW}_{1}>\mathrm{CW}_{1}>\mathrm{DW}_{1}$ (Fig. 1 and Table 4). Daily transpiration was higher for $\mathrm{AW}_{1}$ than for $\mathrm{CW}_{1}$ and $\mathrm{DW}_{1}$. Daily transpiration in 2014 for water-content treatment $W_{1}$ with $50 \%$ rock fragments was $39 \%$ lower than without rock fragments. The descending order of daily transpiration for water-content treatment $\mathrm{W}_{2}$ was: $\mathrm{AW}_{2}>\mathrm{BW}_{2}>\mathrm{CW}_{2}>\mathrm{DW}_{2}$. The differences of daily transpiration between $\mathrm{BW}_{2}$ and $\mathrm{CW}_{2}$ and between $\mathrm{CW}_{2}$ and $\mathrm{DW}_{2}$ in 2014 were significant. Daily transpiration for water-content treatment $\mathrm{W}_{3}$ was similar to that for treatment $\mathrm{W}_{2}$. Daily transpiration for watercontent treatment $\mathrm{W}_{4}$, did not differ significantly among $\mathrm{AW}_{4}, \mathrm{BW}_{4}$ and $\mathrm{CW}_{4}$ in 2014 and among $\mathrm{AW}_{4}, \mathrm{CW}_{4}$ and $\mathrm{DW}_{4}$ in 2015.

Changes in plant transpiration may depend on the ratio of water content between the fine soil and rock fragments. The saturated water content of the rock fragments in this study was $0.08 \mathrm{~g} \mathrm{~g}^{-1}$, which was lower than the field capacity of the fine soil $\left(0.14 \mathrm{~g} \mathrm{~g}^{-1}\right)$. The ratio was higher in the treatments with high water contents than in the treatments with low water contents. The presence of the rock fragments decreased the water content of the stony soil relative to the rock-free soil under well-watered conditions (Tetegan et al., 2015b). The ratio of water content between the fine soil and the rock fragments decreased gradually to 1 or $<1$ when water content decreased. The water content of the stony soil was higher than that in the rock-free soil as the rock-fragment content increased (Tetegan et al., 2015b). The rock fragments therefore had a larger effect on transpiration when water content was high.

The dynamic changes of daily transpiration were similar in the two years (Fig. 1). However, the mean daily transpiration in 2015 were higher than that in 2014 ( $T$ test, $P<0.05$ ), especially in the high water treatments (Table 5 and Fig. 1 ). The mean daily pan evaporation between the two years were not significant (4.84 and $4.97 \mathrm{~mm}$, respectively), which indicated the meteorological factors had little effects on the transpiration. Therefore, the plant growth was the main factor affecting transpiration. Total transpiration, similar to daily transpiration, increased with water content (Table 4), but the response to water content was not as sensitive as for daily transpiration. For example, total transpiration did not dif- fer significantly between $\mathrm{BW}_{3}$ and $\mathrm{BW}_{4}$ in the treatment with $10 \%$ rock-fragment content or between $\mathrm{CW}_{3}$ and $\mathrm{CW}_{4}$ in the treatment with $30 \%$ rock-fragment content. Daily transpiration was thus more suitable for analyzing the response of the plants to water content. The above results for water consumption (transpiration) support our first hypothesis on water consumption.

\subsection{Plant height and basal stem diameter}

The plant heights and basal stem diameters of the korshinsk peashrubs are shown in Fig. 2. The peashrubs grown in the high water treatment were taller and had larger stem diameters than those grown in the low water treatment, regardless of rockfragment content, and this difference increased toward the end of the growing season.

Rock-fragment content did not significantly affect plant height in the three treatments with higher water contents. In the treatment with the lowest water content, the peashrubs grown in the fine soil $\left(\mathrm{AW}_{4}\right)$ and soil with rock-fragment contents of $10 \%\left(\mathrm{BW}_{4}\right)$ or $30 \%\left(\mathrm{CW}_{4}\right)$ were taller than those grown in the soil with $50 \%$ $\left(D_{4}\right)$ rock-fragment content, and this difference increased toward the end of the growing season: $34 \%, 31 \%$ and $35 \%(P<0.05)$ taller at the harvest time, respectively.

Only the peashrubs in the $\mathrm{AW}_{3}$ treatment had larger stem diameters than the plants in the $\mathrm{DW}_{3}$ treatment $(P<0.05)$, and this difference also increased toward the end of the growing season: $27 \%$ larger at the harvest time. Rock-fragment content had no effect on the diameter in the other three water treatments. The above results about plant height and diameter indicated that the peashrubs grown in the soil with $50 \%$ rock-fragment content were shorter and had smaller diameters than the plants in the other three rock-fragment content treatments.

\subsection{Biomass accumulation}

Total and component biomasses were consistent with water content and did not differ significantly between the $\mathrm{W}_{1}$ and $\mathrm{W}_{2}$ treatments for the four rock-fragment contents (Fig. 3). Total and component biomasses were higher in the $\mathrm{W}_{1}$ and $\mathrm{W}_{2}$ treatments than in the other two treatments, with the exception of stem biomass in the treatment with 30\% rock-fragment content, which did not differ significantly among the $\mathrm{W}_{1}, \mathrm{~W}_{2}$ and $\mathrm{W}_{3}$ treatments. Total and component biomasses in the $W_{1}$ and $W_{2}$ treatments varied little between rock-fragment contents of 0,10 and $30 \%$ but were lower at 50\%. Total, stem and leaf biomasses in the $\mathrm{W}_{3}$ treatments were higher with $30 \%$ rock-fragment content than with $10 \%$ and 50\% rock-fragment contents, and root biomass was higher with 0,10 and $30 \%$ rock-fragment contents than with $50 \%$ rockfragment content. Biomass accumulation did not differ significantly among the $\mathrm{W}_{4}$ treatments except for $\mathrm{CW}_{4}$, where leaf biomass was higher than in the other treatments. Biomass was lowest at a rockfragment content of $50 \%(52.35,23.87,7.58$ and $20.91 \mathrm{~g}$ for total, stem, leaf and root biomass, respectively) and highest at a content of $30 \%(86.53,37.29,12.61$ and $36.63 \mathrm{~g}$ for total, stem, leaf and 

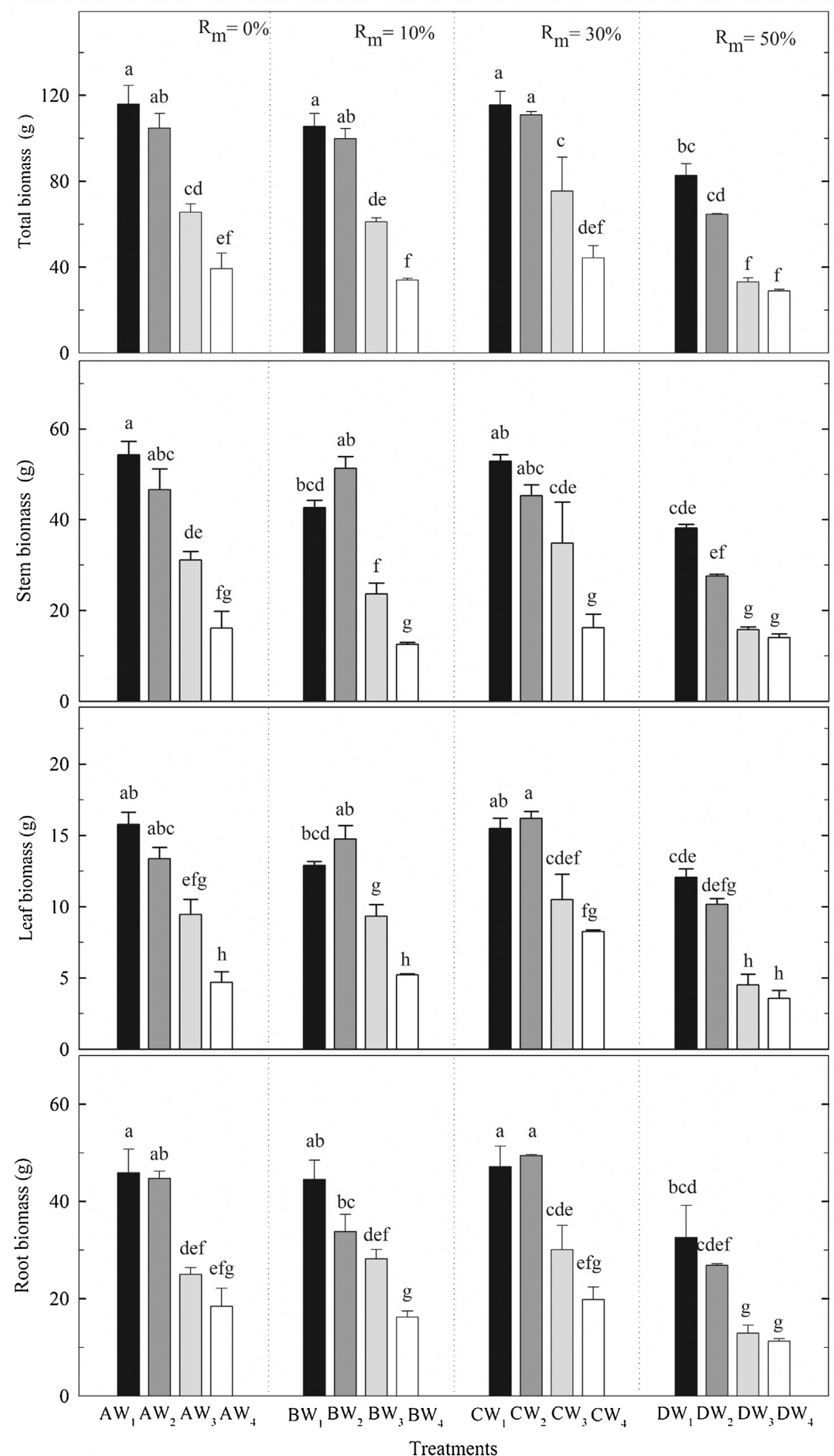

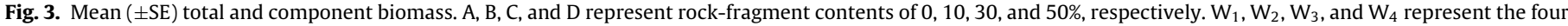

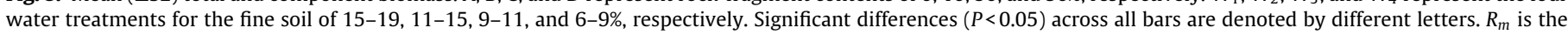
gravimetric rock-fragment content. 


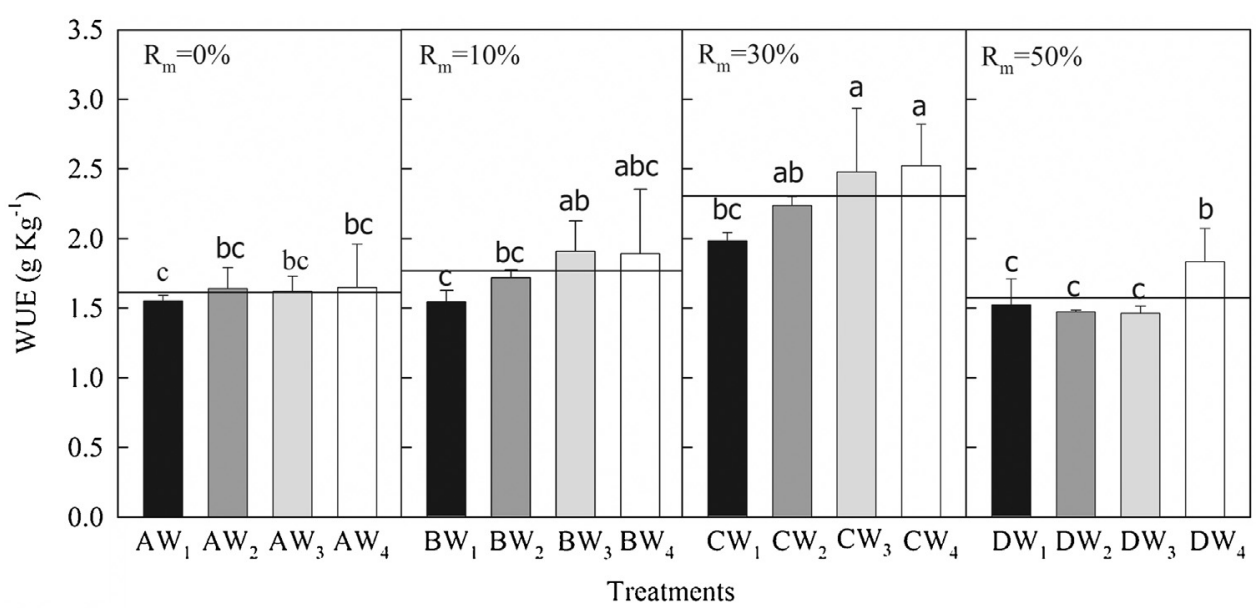

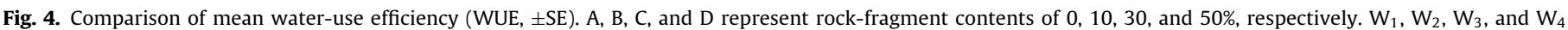

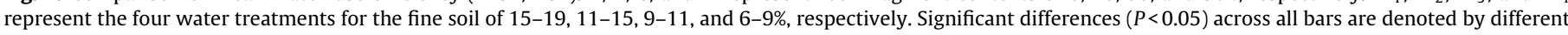
letters. The horizontal line in the figure represents the mean WUE.

root biomass, respectively). Biomass accumulation, however, did not differ significantly among the soils with 0,10 , and $30 \%$ rockfragment contents. The presence of rock fragments did not affect the biomass at low water contents (mean water content in fine soil $<6 \%$, Table 1 ).

We calculated the proportions of stem, leaf and root biomasses of each treatment and then analyzed the variances by an ANOVA. Biomass partitioning was not affected by water or rock-fragment contents in the soil, with the exception of the lower proportion of stem biomass in soil with $30 \%$ rock fragments than in soil with $50 \%$ rock fragments $(-10 \%, P<0.05)$.

Some studies have demonstrated that production and fractional vegetation cover were lower in soils with than without rock fragments (Ercoli et al., 2006; Qin et al., 2015). Other studies have reported that rock fragments in the soil were beneficial to plant growth (Danalatos et al., 1995; Wu et al., 2011a). Rock fragments can improve the conditions of water and temperature. Our results indicated that a rock-fragment content of $30 \%$ had a positive effect on plant growth and biomass, but a content of $50 \%$ rock fragment had a negative effect on plant growth. The negative effects may include the relative inaccessibility of the rock matrix to roots (Bornyasz et al., 2005) or lower nutrient concentrations (EstradaMedina et al., 2013).

\subsection{WUE}

WUE is often considered an important determinant of yield under stress (Blum, 2009). In our study, biomass WUE (or transpiration) was calculated as the ratio between biomass produced and water consumed (transpired). We evaluated the effect of rockfragment content on WUE under water stress. Adding a suitable amount of rock fragments to the soil could increase WUE (Fig. 4). A comparison of the mean WUE of the four water treatments for the different rock-fragment contents indicated that WUE was higher at a content of $30 \%$ than in the other rock-fragment treatments (43, 31 and $46 \%$ higher at 0,10 and $50 \%$ rock-fragment contents, respectively, $P=0.00)$. WUE was therefore highest at a rock-fragment content between 10 and $50 \%$. WUE $\left(2.52 \mathrm{~g} \mathrm{~kg}^{-1}\right)$ at a rock-fragment content of $30 \%$ was highest in the treatment with the lowest water content $\left(\mathrm{CW}_{4}\right)$.

The presence of rock fragments could reduce transpiration, especially under well-watered conditions (Fig. 1 and Table 4), which can increase WUE. The effect of the rock fragments on plant growth is an additional factor. Below a certain threshold, the rock fragments had a positive effect on plant growth. This positive effect of the rock fragments (calcium carbonate concretions) or the range of rock-fragment contents in this study was not significant, but biomass tended to increase with the rock-fragment content (Fig. 3), which can also increase WUE. The rock-fragment content for maximizing biomass may be between 10 and $30 \%$ or between 30 and 50\%. It is necessary to design more meticulous experiment containing more treatments of rock-fragments content to determine the optimum rock-fragments content for plant growth.

Even though the differences of WUE among the water treatments were not significant, WUE tended to increase with the amount of water stress. For example, WUE was $2(P=0.89), 12$ $(P=0.37)$, and $27 \%(P=0.10)$ lower for $\mathrm{CW}_{3}, \mathrm{CW}_{2}$ and $\mathrm{CW}_{1}$, respectively, than for $\mathrm{CW}_{4}$. This result supports the premise that water deficit can increase plant WUE (Meyers et al., 1984; Blum, 2009).

The effects of rock fragments on the characteristics of plants may be species-specific. Korshinsk peashrubs are drought-tolerant leguminous shrubs able to grow in regions with annual precipitation ranging from 100 to $550 \mathrm{~mm}$ Cheng et al. (2013), but they consume a lot of water. Li et al. (2008) and Wang et al. (2010) demonstrated that three-year-old peashrubs could extract soil water from a depth of $500 \mathrm{~cm}$, and Fu et al. (2012) demonstrated that six-year-old peashrubs depleted soil water to a depth of approximately $300 \mathrm{~mm}$ and could extract soil water from a depth of $600 \mathrm{~cm}$. The peashrub also has other relevant characteristics such as deep-rooting and perennially.

Other types of plants such as trees, grasses and crops may respond differently to the presence of rock fragments because of their different growth characteristics and water and nutrient demands. Most studies have focused on one kind of plant. For example, Tetegan et al. (2015b) chose young poplars to study the role of pebbles in water dynamics. Qin et al. (2015) studied the effects of gravel on the properties of the soil and vegetation in an alpine grassland. Smaill et al. (2014) reported an increase in nutrient uptake in stony (2-4 mm) soil for Nothofagus solandri var. cliffortioides and Weinmannia racemosa but did not provide details about the nutrients in these two species. Further comprehensive study is needed to supplement the information on the responses of plant species to the presence of rock fragments, and the applicability of the results of this study to other species of plants should be verified. 


\section{Conclusions}

A column experiment with plants grown in soils with four different rock-fragment contents under four water treatments was conducted for assessing the effect of rock-fragment content on plant water consumption, growth (height and basal stem diameter) and biomass (total biomass and biomasses of stems, leaves and roots) and on the response of WUE to water content. This study provides an approach for increasing WUE in stony areas. The following conclusions can be drawn from this study.

1. Water consumption was affected by the contents of both water and rock fragments. Transpiration first remained stable and then decreased as the water content decreased. Increasing the rock-fragment content in the soil significantly decreased transpiration, especially under well-watered conditions $(>60 \%$ of field capacity).

2. Plants grown in soil with $50 \%$ rock fragments were shorter, had smaller basal stem diameters and had lower biomasses and component biomasses (stems, leaves, and roots) than plants grown in rock-free soil. These parameters did not differ significantly between the plants grown with 10 and 30\% rock fragments, but tended to increase when the rock-fragment content increased from 0 to $30 \%$.

3. WUE first increased and then decreased with increasing gravimetric rock fragment. WUE was lowest for the plants growing in the soil with $50 \%$ rock fragments, but water stress could increase WUE. The rock fragment content to the maximum WUE was in the range from $10 \%$ to $50 \%$. We therefore recommend matching rock-fragment content with maximum WUE when designing strategies of water conservation for stony soils, especially in arid and semiarid areas.

\section{Acknowledgements}

This study was supported by the National Natural Science Foundation of China (41530854 and 41571130081 ). We thank the editor and reviewers for their comments and suggestions that improved the quality of this paper.

\section{References}

Arshad, M.A., Lowery, B., Grossman, B., 1996. Physical tests for monitoring soil quality. In: Doran, J.W., Jones, A.J. (Eds.), Methods for Assessing Soil Quality. SSSA Special Pub. 49 Soil Sci. Soc. Am., Madison, WI, pp. 123-141.

Baetens, J.M., Verbist, K., Cornelis, W.M., Gabriëls, D., Soto, G., 2009. On the influence of coarse fragments on soil water retention. Water Resour. Res. 45, W07408, http://dx.doi.org/10.1029/2008WR007402.

Bielorai, H., 1973. Prediction of Irrigation Needs. Springer Berlin.

Blum, A., 2009. Effective use of water (EUW) and not water-use efficiency (WUE) is the target of crop yield improvement under drought stress. Field Crops Res. $112,119-123$.

Bornyasz, M.A., Graham, R.C., Allen, M.F., 2005. Ectomycorrhizae in a soil-weathered granitic bedrock regolith: linking matrix resources to plants. Geoderma 126, 141-160.

Carrick, S., Palmer, D., Webb, T., Scott, J., Lilburne, L., 2013. Stony soils are a major challenge for nutrient management under irrigation development. In: Currie, L.D., Christensen, C.L. (Eds.), Accurate and Efficient Use of Nutrients on Farms. Occasional Rep. 26. Fertilizer and Lime Research Centre, Massey Univ., Palmerston North, New Zealand.

Cheng, J., Wang, J.B., Cheng, J.M., Luo, Z.K., 2013. Spatial-temporal variability of Caragana korshinskii vegetation growth in the Loess Plateau. Sci. Sil. Sin. 49, 14-20.

Danalatos, N.G., Kosmas, C.S., Moustakas, N.C., Yassouglou, N., 1995. Rock fragments II Their impact on soil physical properties and biomass production under Mediterranean conditions. Soil Use Manage. 11, 121-126.

Ercoli, L., Masoni, A., Mariotti, M., Arduini, I., 2006. Dry matter accumulation and remobilization of durum wheat as affected by soil gravel content. Cereal Res. Commun. 34, 1299-1306.
Estrada-Medina, H., Graham, R.C., Allen, M.F., Jiménez-Osornio, J.J., Robles-Casolco, S., 2013. The importance of limestone bedrock and dissolution karst features on tree root distribution in northern Yucatán, México. Plant Soil 362 (1-2), 37-50.

Feng, Z.W., Wang, X.K., Wu, G., 1999. The Biomass and Productivity of the Forestry Ecosystem in China Beijing. Scientific Publishing, pp. 18-39.

Fu, X., Shao, M., Wei, X., Wang, H., Zeng, C., 2012. Effects of monovegetation restoration types on soil water distribution and balance on a hillslope in northern Loess Plateau of China. J. Hydrol. Eng. 18 (4), 413-421.

Hanks, R.J., Holmes, W.E., Tanner, C.B., 1954. Field capacity approximation based on the moisture-transmitting properties of the soil. Soil Sci. Soc. Am. J. 18, $252-254$

Hou, Q.C., 1993. Comprehensive analysis on natural conditions and environmental harnessing in the experimental area. Memoir of the northwestern institute of soil and water conservation. Acad. Sin. Minist. Water Res. 02, 136-144.

Jia, X.X., Shao, M.A., Wei, X.R., 2011. Estimating total net primary productivity of managed grasslands by a state-space modeling approach in a small catchment on the Loess Plateau, China. Geoderma 160, 281-291.

Li, X.Y., Contreras, S., Solé-Benet, A., 2008. Unsaturated hydraulic conductivity in limestone dolines: influence of vegetation and rock fragments. Geoderma 145 (3), 288-294.

Ma, D.H., Shao, M.A., 2008. Simulating infiltration into stony soils with a dual-porosity model. Eur. J. Soil Sci. 59 (5), 950-959.

Ma, D., Shao, M., Zhang, J., Wang, Q., 2010. Validation of an analytical method for determining soil hydraulic properties of stony soils using experimental data. Geoderma 159 (3), 262-269.

Meyers, R.J.K., Foale, M.A., Done, A.A., 1984. Response of grain sorghum to varying irrigation frequency in the Ord irrigation area. II. Evapotranspiration water-use efficiency. Aust. J. Agric. Res. 35, 31-42.

Novák, V., Kňava, K., 2012. The influence of stoniness and canopy properties on soil water content distribution: simulation of water movement in forest stony soil. Eur. J. For. Res. 131 (6), 1727-1735.

Novák, V., Kňava, K., Šimůnek, J., 2011. Determining the influence of stones on hydraulic conductivity of saturated soils using numerical method. Geoderma 161 (3), 177-181.

Poesen, J., Lavee, H., 1994. Rock fragments in top soils: significance and processes. Catena 23 (1), 1-28

Qin, Y., Yi, S., Chen, J., Ren, S., Ding, Y., 2015. Effects of gravel on soil and vegetation properties of alpine grassland on the Qinghai-Tibetan plateau. Ecol. Eng. 74, 351-355.

Schwinning, S., 2013. Do we need new rhizosphere models for rock-dominated landscapes? Plant Soil 362 (1-2), 25-31.

Shao, M.A., Ma, D.H., Zhu, Y.Y., 2009. Study on Soil Water in Stony Soil on the Loess Plateau. Scientific Publishing, Beijing.

Sinclair, T.R., Hammond, L.C., Harrison, J., 1998. Extractable soil water and transpiration rate of soybean on sandy soils. Agron. J. 90 (3), 363-368.

Smaill, S.J., Clinton, P.W., Allen, R.B., Davis, M.R., 2014. New evidence indicates the coarse soil fraction is of greater relevance to plant nutrition than previously suggested. Plant Soil 374 (1-2), 371-379.

Tetegan, M., Nicoullaud, B., Baize, D., Bouthier, A., Cousin, I., 2011. The contribution of rock fragments to the available water content of stony soils: proposition of new pedotransfer functions. Geoderma 165, 40-49.

Tetegan, M., de Forges, A.R., Verbeque, B., Nicoullaud, B., Desbourdes, C., Bouthier, A., Cousin, I., 2015a. The effect of soil stoniness on the estimation of water retention properties of soils: a case study from central France. Catena 129, 95-102.

Tetegan, M., Korboulewsky, N., Bouthier, A., Samouëlian, A., Cousin, I., 2015b. The role of pebbles in the water dynamics of a stony soil cultivated with young poplars. Plant Soil 391 (1-2), 307-320.

Van Wesemael, B., Poesen, J., Kosmas, C.S., Danalatos, N.G., Nachtergaele, J., 1996. Evaporation from cultivated soils containing rock fragments. J. Hydrol. 182 (1), 65-82.

Wang, Y., Shao, M., Shao, H., 2010. A preliminary investigation of the dynamic characteristic of dried soil layers on the Loess Plateau of China. J. Hydrol. (Amsterdam) 381 (1-2), 9-17.

Wu, Y., Huang, M., Warrington, D.N., 2011a. Growth and transpiration of maize and winter wheat in response to water deficits in pots and plots. Environ. Exp. Bot. $71(1), 65-71$.

Wu, Y., Huang, M., Gallichand, J., 2011b. Transpirational response to water availability for winter wheat as affected by soil textures. Agric. Water Manage. 98 (4), 569-576.

Wu, X., Zhao, L., Fang, H., Chen, J., Pang, Q., Wang, Z., Chen, M., Ding, Y., 2011c. Soil enzyme activities in permafrost regions of the western Qinghai-Tibetan plateau. Soil Sci. Soc. Am. J. 76, 1280-1289.

Zhou, B.B., Shao, M.A., Shao, H.B., 2009. Effects of rock fragments on water movement and solute transport in a Loess Plateau soil. C. R. Geosci. 341 (6), $462-472$

Zhu, Y., Shao, M., 2008. Spatial distribution of surface rock fragment on hill-slopes in a small catchment in wind-water erosion crisscross region of the Loess Plateau. Sci. China Series D: Earth Sci. 51 (6), 862-870. 